\title{
SPATIAL VARIABILITY OF APPARENT ELECTRICAL CONDUCTIVITY AND PHYSICOCHEMICAL ATTRIBUTES OF THE SOIL
}

\author{
Elizeu de Souza Lima ${ }^{1 *}$, Lenon Henrique Lovera ${ }^{1}$, Rafael Montanari², Zigomar Menezes de \\ Souza $^{3}$, Jose Luiz Rodrigues Torres ${ }^{4}$

\footnotetext{
${ }^{1}$ Doutorando no Programa de Pós-Graduação em Engenharia Agrícola - Universidade de Campinas, Faculdade de Engenharia Agrícola, Campinas-SP. *Email: elizeu.florestal@gmail.com

2 Professor Doutor do Departamento de Fitossanidade, Engenharia Rural e Solos - Universidade Estadual Paulista (UNESP), Faculdade de Engenharia, Campus de Ilha Solteira-SP

${ }^{3}$ Professor Doutor da Universidade de Campinas, Faculdade de Engenharia Agrícola, Campinas-SP.

${ }^{4}$ Professor Doutor do Instituto Federal do Triângulo Mineiro, Câmpus de Uberaba-MG.
}

\begin{abstract}
The apparent electrical conductivity has been an attribute widely used in studies of spatial variability, due to its high correlation with other soil attributes and because it is an attribute that represents the variability of an area in a quick, easy and low-cost way. The objective of this study was to evaluate the relationship between the spatial variability of apparent electrical conductivity with physicochemical attributes of an Eutrophic Red Oxisol located in Maracaju, state of Mato Grosso do Sul, Brazil, for determining specific soil management zones. We analyzed apparent electrical conductivity attributes (ECa 2, 7 and 15 $\mathrm{kHz}$ ), contents of potassium, cation exchange capacity, clay, base saturation and organic matter content. ECa was measured with the Profiler EMP-400 crossing the entire area in 0.45 $\mathrm{m}$ spaced lines. Soil samples were collected in the $0.00-0.20 \mathrm{~m}$ layer, with a total of 216 samples in an area of 70 ha. Statistical and geostatistical analyses were performed by SAS and $\mathrm{GS}^{+}$software. The apparent electrical conductivity (ECa) was presented as an important tool to identify specific management zones showing data variability between low and medium zones. The attributes that had higher correlation with apparent electrical conductivity were potassium and clay.
\end{abstract}

Key words: Geostatistics. Management zones. Precision agriculture.

\section{VARIABILIDADE ESPACIAL DA CONDUTIVIDADE ELÉTRICA APARENTE E DOS ATRIBUTOS FÍSICO-QUIMICOS DO SOLO}

RESUMO: A condutividade elétrica aparente tem sido um atributo amplamente utilizado em estudos de variabilidade espacial, devido a sua elevada correlação com outros atributos do solo e por ser um atributo que representa a variabilidade de uma área de forma rápida, fácil e com baixo custo. $\mathrm{O}$ objetivo deste estudo foi avaliar a relação entre a variabilidade espacial da condutividade elétrica aparente com atributos físicos e químicos de um Latossolo Vermelho eutrófico localizado em Maracaju-MS, para a determinação das zonas específicas de manejo do solo. Foram analisados os atributos condutividade elétrica aparente (CEa 2, 7 e $15 \mathrm{kHz}$ ), teores de potássio, capacidade de troca catiônica, argila, saturação por bases e teor de matéria orgânica. A CEa foi medida com o Profiler EMP400 atravessando toda a área em Cultura Agronômica, Ilha Solteira, v.26, n.3, p.469-482, 2017 
linhas espaçadas de 0,45 m. As amostras de solo foram coletadas na camada de 0,00-0,20 m, com um total de 216 amostras em uma área de 70 ha. A análise estatística e geoestatística foram realizadas por meio dos softwares SAS e GS+. A condutividade elétrica aparente (CEa) apresentou-se como uma importante ferramenta para identificar zonas específicas de manejo apresentando variabilidade dos dados entre baixa e média; os atributos que apresentaram maior correlação com a condutividade elétrica aparente foram o potássio e a argila.

Palavras-chave: Geoestatística. Zonas de manejo. Agricultura de precisão.

\section{INTRODUCTION}

New technologies of direct or remote sensing of environmental factors have been developed for used in precision agriculture to manage production considering the spatial variability in productivity and the factors related to it, and among these are the sensors for monitoring physicochemical soil attributes, where it is possible to highlight those that monitor their apparent electrical conductivity (ECa).

ECa has been widely used in studies on spatial variability due to its high correlation with other attributes of the soil and with the productivity of cultivated crops (LESCH et al., 2005; SIQUEIRA et al., 2015), since it is directly related to the water content in the soil, texture, organic matter, pore size and distribution, salinity, capacity of cation exchange, base saturation and electrolyte concentration in soil solution (SIQUEIRA et al., 2015; BERNARDI et al., 2015). In addition to this direct relationship with these attributes, the ECa of the soil is characterized by being an attribute that represents the spatial variability of the area in a quick, easy and low-cost way (BOTTEGA et al., 2015).

Soil fertility has been noted as the principal agent of spatial variability in productivity and chemical soil attributes (SOUSA et al., 2016) and base saturation has been one of the most used indicators to evaluate this fertility because it has the ability to interfere with the provision of various essential elements to plant development, in which the ions that consist the soil solution can be adsorbed to particles of clay and organic matter, absorbed by plants or leachate from surface layers via soil erosion (AQUINO et al., 2014; FRANCISCO et al., 2015).

In a study, Corassa et al. (2016) noted that the soil ECa is regulated by $\mathrm{pH}$, the sum of the concentrations of ions and by soluble carbon where the increase in ECa occurs because of the decrease in the $\mathrm{pH}$ and the addition of soluble carbon + ion concentration. ECa is correlated with $\mathrm{pH}, \mathrm{V}, \mathrm{Ca}^{2+}, \mathrm{Mg}^{2+}, \mathrm{Al}^{3+}$ and saturation by $\mathrm{Al}^{3+}$, which can be used as a predictor of buffer effect of base saturation (V\%) and the need for liming. Studying the correlation between ECa and spatial variability of soil attributes, Bottega et al. (2015) observed simple linear correlations between these parameters evaluated and positive correlations with chemical soil attributes.

Cultura Agronômica, Ilha Solteira, v.26, n.3, p.469-482, 2017 
To perform the quality evaluation of soil chemistry is necessary to collect a large number of soil samples, and geostatistics has been used to analyze and correlate all the data generated. Through it, we can investigate the magnitude of the correlation between the samples and their similarity with the distance, being that spatial dependence is analyzed by semi-variograms adjustments (SOUSA et al., 2016). When sampling points of an area are georeferenced, geostatistics provides obtainment of detailed spatial variability of its fertility from data processing and obtainment of maps (LAMPARELLI et al., 2001), with a larger of number of samples increasing the accuracy of results.

According to Corá and Beraldo (2006), the generation of fertility maps can be made through the sampled points interpolation by kriging, which is based on spatial dependence expressed in the semi-variogram between neighbor sampling points to estimate values in any position inside the field, without trend and with minimum variance.

Few studies have been conducted to evaluate the relationship of ECa with productivity, nutrient dynamics and physical attributes of the soil; however, knowing the dynamics of these relationships in soil solution became an important practice, since critical levels of nutrients are scarce in the literature. Thus, the objective of our study was to evaluate the relationship between spatial variability of apparent electrical conductivity and physicochemical attributes of an Eutrophic Red Oxisol located in Maracaju, state of Mato Grosso do Sul, Brazil, for determining specific soil management zones.

\section{MATERIAL AND METHODS}

The study was conducted in Fortaleza Farm, located in Maracaju-MS, Brazil, situated at $22^{\circ} 01^{\prime} 44.39^{\prime \prime} \mathrm{S}$ and $55^{\circ} 17^{\prime} 23.29^{\prime}$ ' $\mathrm{W}$ and average altitude of $400 \mathrm{~m}$ in the agricultural year 2013/2014 in an area with approximately 20 years of use as pasture (Urochloa decumbens). After the collections of soil samples for chemical analysis, the pasture was managed for growing soybeans.

The climate of the region, according to Koppen's classification, is defined as Humid Mesothermal, Cwa type, with average annual temperatures and precipitation ranging from $20^{\circ}$ to $24^{\circ} \mathrm{C}$ and 1,250 to $1,500 \mathrm{~mm}$ (PESQUEIRA et al., 2016).

Soil was classified as Eutrophic Red Oxisol (EMBRAPA, 2013), clay texture, and slightly wavy relief.

An regular sampling grid was georeferenced, with a GPS equipment containing 216 points randomly distributed (Figure 1), aiming to cover the area of 70 ha of the parcel of land. A simple sample of soil in the 0.00-0.20 m layer soil with the aid of a Dutch Auger was collected at each sampling point. The soil was collected to determine contents of potassium $(\mathrm{K})$, cation exchange capacity (CEC), base saturation (V), organic matter (OM) and determination of clay, according to Embrapa (2011) and Raij et al. (2001).

Cultura Agronômica, Ilha Solteira, v.26, n.3, p.469-482, 2017 


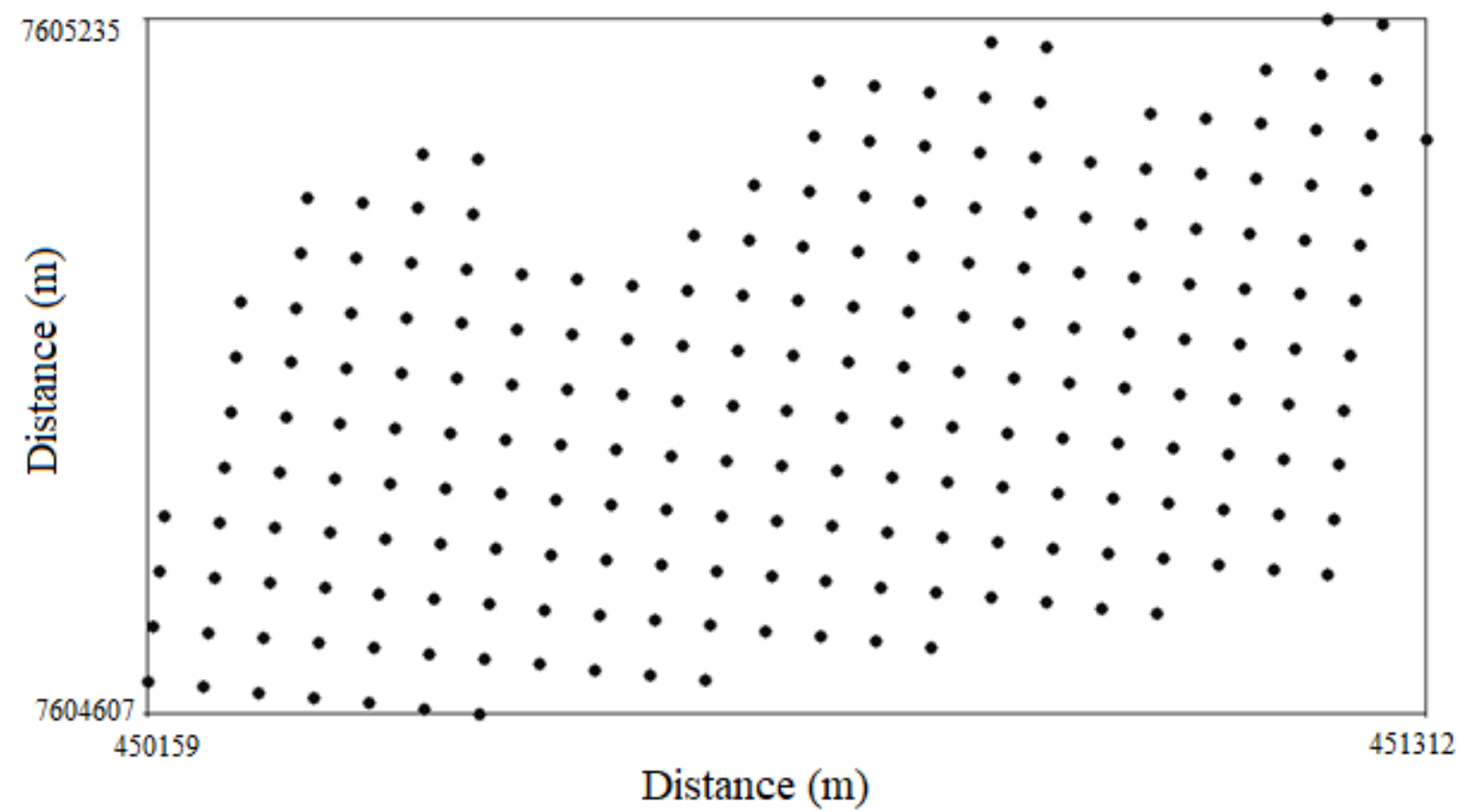

Figure 1. Sketch grid sampling.

The apparent electrical conductivity (ECa) of the soil was measured in the frequencies of 2, 7 and $15 \mathrm{kHz}$ through the equipment Profiler EMP-400 (GEOPHYSICAL SURVEY SYSTEMS, 2006) without direct contact with the soil, in the same sampling points where soil samples were collected. These frequencies were chosen because they represent the top, bottom and middle of the frequency range available for measurement. Measurements were carried out with a Profiler model that crossed the whole area in spaced lines of $0.45 \mathrm{~m}$ and 1.0 $\mathrm{m}$ above the ground level on a PVC support, this being dragged by a quadricycle across the land.

Electromagnetic induction is a non-invasive technique, which allows the determination of ECa by the transmission procedure of a magnetic field in the soil, where it is possible to send propagation current and consider only conduction currents. ECa measurement equipment by electromagnetic induction worked using lower frequencies $(<1 \mathrm{MHz})$.

For each analyzed attribute, the classical descriptive analysis was carried out with the aid of statistical software SAS, where the mean, median, minimum and maximum values, standard deviation, coefficient of variation, asymmetry kurtosis and frequency distribution were calculated (SCHLOTZHAVER; LITTELL, 1997).

The statistic of Shapiro e Wilk was used with 5\% probability to test the hypothesis of normality. Correlation matrix was set, aiming to make the simple linear correlations for the combinations, two at a time, among all the attributes evaluated as well as introducing regression analyses for the pairs of greatest interest. Separately for each attribute, spatial dependence was analyzed by simple semi-variogram calculation, based on the stationary assumptions of the intrinsic hypothesis, by using the $\mathrm{GS}^{+}$package (GAMMA DESIGN SOFTWARE, 2004).

Cultura Agronômica, Ilha Solteira, v.26, n.3, p.469-482, 2017 
Adjustments of simple semi-variograms, due to their models, were carried out primarily by the initial selection of: a) least mean square of deviations (LMSD); b) highest determination coefficient $\left(\mathrm{r}^{2}\right)$; and c) greater spatial dependence estimator (SDE). The final decision of the model that represented the adjustment was performed by cross-validation, as well as for size definition of the neighborhood that provided the best kriging grid, performed by kriging. For each attribute, the nugget effect $\left(\mathrm{C}_{0}\right)$, range $\left(\mathrm{A}_{\mathrm{o}}\right)$ and sill $\left(\mathrm{C}_{\mathrm{o}}+\mathrm{C}\right)$ were related. The spatial dependence estimator (SDE) analysis was performed according to the following expression (GAMMA DESIGN SOFTWARE, 2004):

$$
\mathrm{SDE}=\left[\mathrm{C} /\left(\mathrm{C}+\mathrm{C}_{\mathrm{o}}\right)\right] \times 100
$$

Where SDE is the spatial dependence estimator; $\mathrm{C}$, the structural variance; and $\mathrm{C}+\mathrm{C}_{0}$, the sill.

The proposed interpretation to the SDE was the following: SDE $\leq 20 \%$ - spatial variable with very low dependence; $20 \%<\mathrm{SDE} \leq 40 \%$ - spatial variable with low dependence; $40 \%$ $<\mathrm{SDE} \leq 60 \%$ - spatial variable with medium dependence; $60 \%<\mathrm{SDE} \leq 80 \%$ - spatial variable with high dependence; and $80 \%<\mathrm{SDE} \leq 100 \%$-spatial variable with very high dependence (DALCHIAVON; CARVALHO, 2012).

\section{RESULTS AND DISCUSSION}

Analyzing the data listed on Table 1, we observe that average values found for potassium (K), cationic exchange capacity (CEC), clay content (CL), base saturation (V\%) and organic matter $(\mathrm{OM})$ showed average contents of $4.47 \mathrm{mmol}_{\mathrm{c}} \mathrm{dm}^{-3}, 36.12 \mathrm{mmol}_{\mathrm{c}} \mathrm{dm}^{-3}$, $664.87 \mathrm{~g} \mathrm{~kg}^{-1}, 59.49 \%$ and $29.37 \mathrm{~g} \mathrm{dm}^{-3}$, respectively. These values indicate that this soil presents average levels of fertility, according to Raij (2001), and also that these pasture lands are being well managed, since in areas under pasture of Urochloa decumbens it is common to find acidic and poor in fertility soils.

According to Aquino et al. (2014), in well managed pastures, it is common to find high values of $\mathrm{K}, \mathrm{CEC}$ and $\mathrm{V} \%$ in the topsoil, because losses of cations in these areas are minimized due to prevention and control of erosion processes, which related to the correction of soil acidity and nutrient replenishment via fertilizing maintain soil fertility at adequate levels. Caetano et al. (2013), when studying the chemical properties of an Oxisol Red under different use and management systems, observed in those areas, where there was no proper management of pasture, that the soil was poor in fertility, in acids, and feature low CEC and $\mathrm{V} \%$.

Results of CL and OM corroborate those found by Tavares Filho et al. (2012), who assessed an Eutrophic Red Oxisol in the 0.00-0.20 m layer and found 650 clay contents of $650 \mathrm{~g} \mathrm{~kg}^{-1}$ and $\mathrm{OM}$ of $23.89 \mathrm{~g} \mathrm{dm}^{-3}$, demonstrating that there is no variation in both soils evaluated regarding contents of organic matter and clay.

Cultura Agronômica, Ilha Solteira, v.26, n.3, p.469-482, 2017 
Table 1. Descriptive analysis of apparent electrical conductivity and physicochemical attributes of the soil collected at a depth of 0.00-0.20 m.

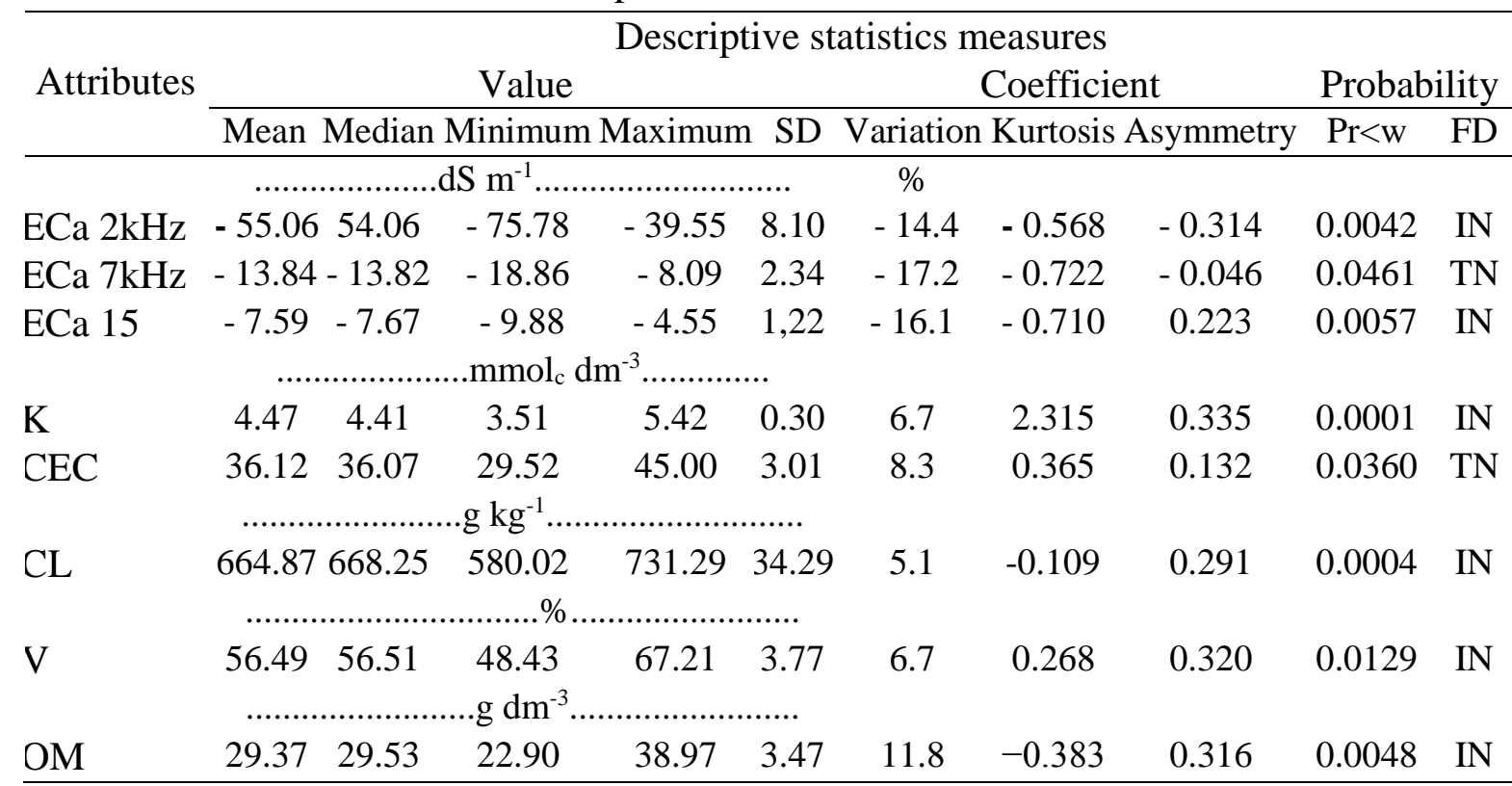

$\mathrm{ECa}=$ apparent electrical conductivity, $\mathrm{K}=$ Potassium, $\mathrm{CEC}=$ cation exchange capacity, $\mathrm{CL}=\mathrm{Clay}, \mathrm{V}=$ base saturation, $\mathrm{OM}=$ organic matter content, $\mathrm{SD}=$ standard deviation, $\mathrm{FD}=$ frequency distribution, $\mathrm{IN}=$ indetermined, $\mathrm{TN}=$ tending to normal.

According to the classification of the coefficient of variation proposed by PimentelGomes and Garcia (2002), the variability of an attribute can be classified according to the magnitude of its coefficient of variation. The apparent electrical conductivity (ECa) of 2, 7 and $15 \mathrm{kHz}$ presented values of $-55.06,-13.84$ and $7.59 \mathrm{dS} \mathrm{m}^{-1}$, with coefficient of variation $-14.4,-17.2$ and $-16.1 \%$, standard deviation (SD) of 8.10, 2.34 and $1.22 \mathrm{dS} \mathrm{m}^{-1}$, respectively (Table 1). The coefficient of variation data, associated with SD and ECa, showed the magnitude of variability of the properties analyzed due to the high variation that occurred.

Values of K, CEC, CL and V\% presented lower variability with coefficient of variation between 5.1 and 8.3\%. Carvalho et al. (2013), when studying the variability of physical attributes of an Oxisol found average variability of $17.4 \%$ for clay content, disagreeing with the data found in this study.

The OM content presented average variability with coefficient of variation of $11.8 \%$ (Table 1). Marques Junior et al. (2008), when studying an Oxisol Red, also found average variability of $12.9 \%$ for the $\mathrm{OM}$. The coefficient of variation must be used as a parameter to validate the average values found, since according to Pimentel-Gomes and Garcia (2002), when coefficient of variation is greater than $30 \%$, the average has little significance because it reflects that the data series is very heterogeneous, annulling the average reliability. However, if it is less than $20 \%$, data are homogeneous and average has significance and can be used as representative for the data obtained.

When any statistical variable has frequency distribution of normal type, the measure of central tendency most suited to represent it should be the average. On the other hand, it will 
be by the median if there is distribution of frequencies of the indeterminate type and tending to normal (DALCHIAVON et al., 2011). For ECa of 2 and $15 \mathrm{kHz}$, presented frequency distribution of indetermined type, and for $\mathrm{ECa}$ of $7 \mathrm{kHz}$, presented frequency distribution tending to normal with negative asymmetry coefficients of -0.314 and positive of 0.046 and 0.223 , respectively (Table 1$)$. Kurtosis coefficients were negative $(-0.568,-0.722$ and -0.710 , respectively) and $5 \%$ of probability was not significant by the normality test, since its probability ranged from 0.0057 to 0.0461 .

The attributes K, CL, V and OM presented frequency distribution of indetermined type with asymmetry coefficients between 0.132 and 0.335 , and kurtosis between -0.383 and 0.365 , not being significant at $5 \%$ of probability by the normality test, since it ranged between 0.0001 and 0.0360 , respectively (Table 1). Thus, the central tendency of measures of all attributes evaluated will be the median. Therefore, indeterminate frequency distributions, as well as the magnitude of the kurtosis and asymmetry coefficients, were in accordance with the results obtained by Dalchiavon et al. (2011) and Machado et al. (2015), who verified distribution frequency of indetermined type for all evaluated attributes.

The positive asymmetry values demonstrated that there is a concentration trend of values below the average observed, and this trend is more expressive the higher the value obtained. The reverse situation occurs for negative values of this coefficient (Table 1). Except the $\mathrm{CL}$ and $\mathrm{OM}$ that presented platykurtic frequency distribution, i.e., negative kurtosis, the remaining attributes of the soil had leptokurtic frequency distribution, showing that most of the soil attributes have the data near the center in their frequency distribution chart. This may indicate that measures of central tendency are not dominated by atypical values in the distribution. It was also observed that, except CL, all attributes evaluated showed similar mean and median values, and according to Bottega et al. (2015), this indicates that data tend to a symmetrical distribution.

Table 2. Array of linear correlation between apparent electrical conductivity and physicochemical attributes of the soil collected at a depth of 0.00-0.20 m.

\begin{tabular}{|c|c|c|c|c|c|c|c|}
\hline \multirow{2}{*}{ Attributes } & \multicolumn{7}{|c|}{ Correlation coefficient } \\
\hline & $2 \mathrm{kHz}$ & $7 \mathrm{kHz}$ & $15 \mathrm{kHz}$ & K & CEC & $\mathrm{CL}$ & $\mathrm{V} \%$ \\
\hline ECa $7 \mathrm{kHz}$ & $0.719 * *$ & - & - & - & - & - & - \\
\hline ECa $15 \mathrm{kHz}$ & $0.305 *$ & $0.617 * *$ & - & - & - & - & - \\
\hline $\mathrm{K}$ & $-0.369 *$ & 0.014 & 0.031 & - & - & - & - \\
\hline $\mathrm{CEC}$ & -0.154 & -0.032 & 0.121 & $0.283 *$ & - & - & - \\
\hline CL & $0.378 *$ & $0.281 *$ & -0.006 & -0.144 & $-0.677 *$ & - & - \\
\hline $\mathrm{V}$ & 0.013 & 0.093 & 0.096 & $0.341 *$ & $0.912 * *$ & $-0.455^{*}$ & - \\
\hline $\mathrm{OM}$ & $-0.209 *$ & -0.137 & 0.096 & 0.115 & 0.165 & $-0.232 *$ & -0.029 \\
\hline
\end{tabular}

$\mathrm{ECa}=$ apparent electrical conductivity, $\mathrm{K}=$ potassium, $\mathrm{CEC}=$ cation exchange capacity, $\mathrm{CL}=$ clay, $\mathrm{V}=$ base saturation, $\mathrm{OM}=$ organic matter content. *Significant at $5 \%$, ** Significant at $1 \%$.

Correlations between ECa and soil attributes were significant for $2 \mathrm{kHz} \times \mathrm{CL}$ ( $\mathrm{r}=$ $\left.0.378^{*}\right), 2 \mathrm{kHz} \times \mathrm{OM}\left(\mathrm{r}=-0.209^{*}\right)$ and $7 \mathrm{kHz} \times \mathrm{CL}\left(\mathrm{r}=0.281^{*}\right)$. This significance showed that apparent electrical conductivity is correlated with clay content and organic matter of the 
soil (Table 2). For Kilic et al. (2012), soils with higher clay content conduct more electricity compared with those of sandy texture due to the fact that ions present in the diffuse doublelayer of clay particles are able to conduct greater electrical current even when the soils present low contents of water, whereas sand practically does not have this feature.

For the $2 \mathrm{kHz}$ x K correlations and $2 \mathrm{kHz} \times \mathrm{OM}$, there were inverse correlation (Table 2). This inverse correlation indicated that, with the decrease of $\mathrm{K}$ and $\mathrm{OM}$ in the soil, the frequency of ECa increased. For $2 \mathrm{kHz}$ x CL and $7 \mathrm{kHz}$ x CL there was direct correlation, i.e., with increase in the ECa frequency, there was a significant increase of clay content in the soil studied. According to Machado et al. (2006), the direct and positive correlation occurs due to greater presence of ions in clay particles that are able to conduct increased electricity, even though this soil showed low contents of water, whereas sand practically does not have this feature, thus the results of ECa in clay soils are generally higher than on sandy soils. These results differed from the ones found by Machado et al. (2015), with a direct correlation for 2 $\mathrm{kHz} \times \mathrm{CEC}(\mathrm{r}=0.561 * *), 2 \mathrm{kHz} \times \mathrm{OM}\left(\mathrm{r}=0.172^{* *}\right)$ and $7 \mathrm{kHz} \times \mathrm{OM}\left(\mathrm{r}=0.241^{* *}\right)$ correlations.
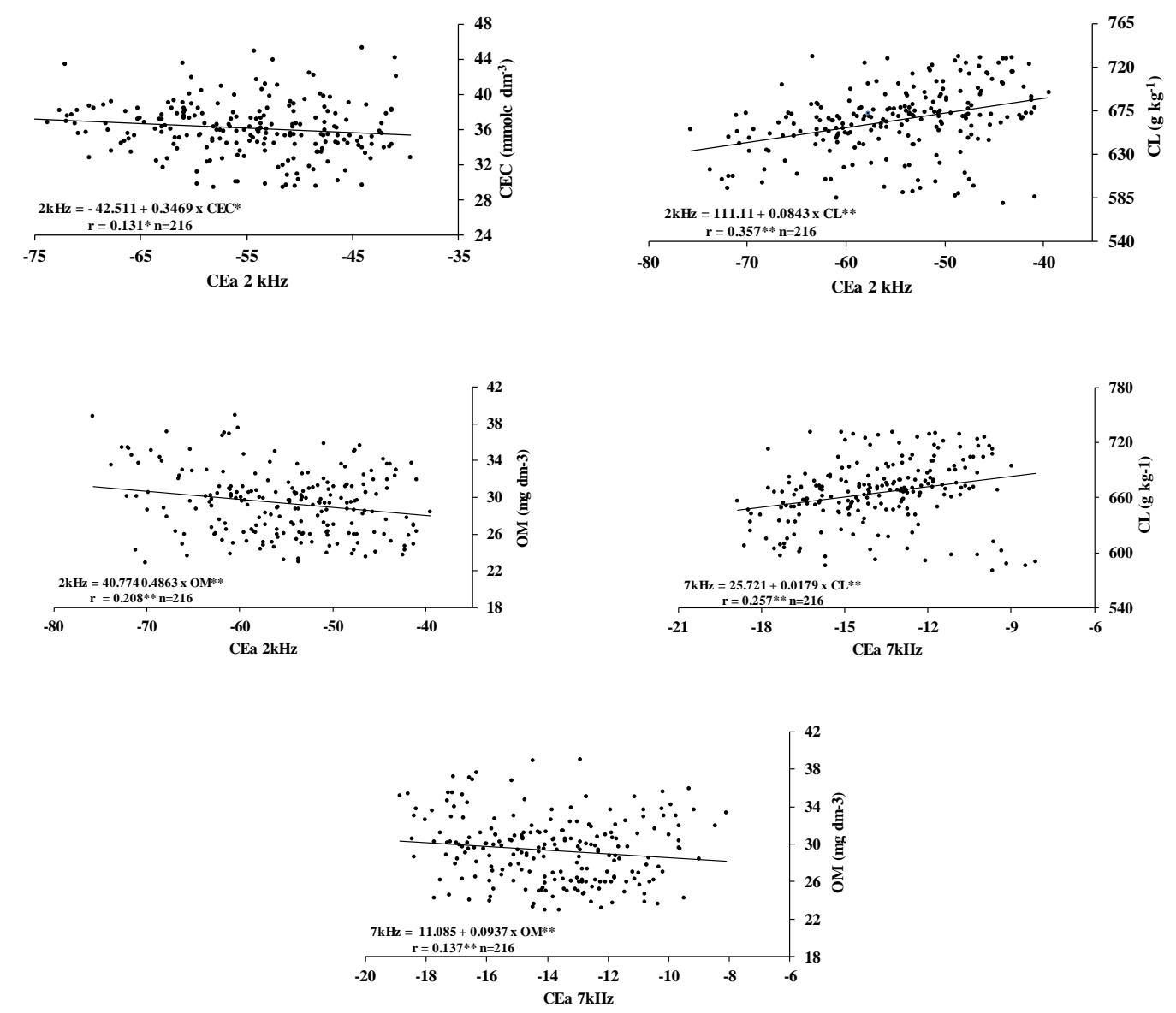

Figure 2. Regression equations between apparent electrical conductivity and physicochemical attributes of the soil collected in the depths of 0.00-0.20 m. 
Figure 2 shows regression equations between the attributes ECa ( 2 and $7 \mathrm{kHz})$ and CEC, CL and OM. For Hopkins (2014), correlation coefficients lower than 0.5 indicate weak correlation, and above this value they are considered strong correlation. Thus, all figures present weak correlation, although significant, with correlation coefficient lower than 0.357 .

Geostatistical analysis showed that, for most of the attributes studied, there was spatial dependence for the data, except for clay, OM and V, being that, ECa $2 \mathrm{kHz}$ was adjusted to the spherical model, ECa 7 and $15 \mathrm{kHz}$, exponential model and soil attributes, to the gaussian model (Table 3 and Figure 3).

Table 3. Parameters of semi-variograms and cross-validations for apparent electric conductivity and physicochemical attributes of the soil collected at a depth of 0.00-0.20 m.

\begin{tabular}{|c|c|c|c|c|c|c|c|c|c|c|c|}
\hline \multirow{3}{*}{ Attributes } & \multicolumn{11}{|c|}{ Parameters } \\
\hline & \multirow[t]{2}{*}{ Model } & \multirow{2}{*}{ 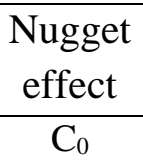 } & \multirow{2}{*}{$\begin{array}{c}\text { Sill } \\
\mathrm{C}_{0}+\mathrm{C}\end{array}$} & \multirow{2}{*}{$\begin{array}{l}\text { Range } \\
\mathrm{A}_{0}(\mathrm{~m})\end{array}$} & \multirow[t]{2}{*}{$r^{2}$} & \multirow[t]{2}{*}{ SSR } & \multicolumn{2}{|c|}{ SDE } & \multicolumn{3}{|c|}{ Cross-validation } \\
\hline & & & & & & & $\%$ & Class & $\mathrm{a}$ & $\mathrm{b}$ & $\mathrm{r}$ \\
\hline ECa 2 & Sph & 35.50 & 83.820 & 1032 & 0.938 & 1.42 & 57.9 & $\mathrm{HI}$ & 2.14 & 1.039 & 0.557 \\
\hline $\mathrm{ECa} 7$ & Exp & 3.00 & 6.844 & 885 & 0.745 & 3.59 & 56.2 & VH & 1.39 & 1.102 & 0.607 \\
\hline ECa 15 & Exp & 0.684 & 1.619 & 396 & 0.832 & 0.038 & 57.8 & HI & 0.61 & 1.079 & 0.533 \\
\hline K & Gau & 0.008 & 0.115 & 190.5 & 0.974 & $20.10^{-4}$ & 93.0 & VH & 0.12 & 0.972 & 0.919 \\
\hline CEC & Gau & 0.010 & 8.187 & 247.7 & 0.974 & 2.12 & 99.9 & VH & -0.04 & 1.001 & 0.998 \\
\hline CL & Pne & 1200 & 1200 & - & - & - & - & - & - & - & - \\
\hline V & Pne & 14.06 & 14.06 & - & - & - & - & - & - & - & - \\
\hline OM & Pne & 12.25 & 12.25 & - & - & - & - & - & - & - & - \\
\hline
\end{tabular}

$\mathrm{ECa}=$ apparent electrical conductivity $(\mathrm{kHz}), \mathrm{K}=$ Potassium, $\mathrm{CEC}=$ cation exchange capacity, $\mathrm{CL}=$ Clay, $\mathrm{V} \%$ $=$ base saturation, $\mathrm{OM}=$ organic matter content, $\mathrm{Sph}=$ Spherical, $\mathrm{Exp}=$ Exponential, Gau $=$ Gaussian, Pne $=$ Pure nugget effect, $\mathrm{SSR}=$ sum of squares of residues, $\mathrm{SDE}=$ spatial dependence estimator $(\mathrm{HI}=$ high and VH $=$ very high).

Dalchiavon et al. (2011), studying a Oxisol Red dystrophic under direct seeding system, on a grid with 75 sampling points with spacing between points of $10 \mathrm{~m} \times 10 \mathrm{~m}$, totaling 7,500 $\mathrm{m}^{2}$, found a Gaussian model modeling the chemical soil attributes. According to Dalchiavon et al. (2012), the lack of spatial independence for the attributes evaluated in the study means that the behavior of these regionalized attributes was not random and that the distances between points collected and used in the geostatistical gridding were enough for the study of spatial variability.

The performance of semi-variograms (Table 3), considering values of the determination coefficient $\left(\mathrm{r}^{2}\right)$, had the following descending relation: K (0.974), CEC (0.974), ECa $2 \mathrm{kHz}$ (0.938), ECa $15 \mathrm{kHz}(0.832)$ and ECa $7 \mathrm{kHz}(0.745)$. Thus, in the relation among the first three attributes $(\mathrm{K}, \mathrm{CEC}$ and $\mathrm{ECa} 2 \mathrm{kHz}$ ) that had high determination coefficients, the following was observed: CEC seemed to be the attribute of best semivariographic adjustment with SDE of $99.9 \%$, considered as very high, range of $247.7 \mathrm{~m}$ and is also the attribute that is best adjusted among the models presented.

Cultura Agronômica, Ilha Solteira, v.26, n.3, p.469-482, 2017 
We observed that all attributes analyzed were adjusted to some semi-variogram model, and there was no pure nugget effect to any of the attributes analyzed, indicating random distribution in the study zone and spatial independence (CRUZ et al., 2010). The highest determination coefficient $\left(\mathrm{r}^{2}\right)$ for the ECa went to the ECa $2 \mathrm{kHz}$ with SDE of 57.9\%, considered high, and range of $1,032 \mathrm{~m}$. These results differed from the ones found by Machado et al. (2015). They found better performance of semi-variograms for the attributes $\mathrm{ECa} 2 \mathrm{kHz}$ and $\mathrm{ECa} 7 \mathrm{kHz}$; however, SDE was similar and very high for most attributes.
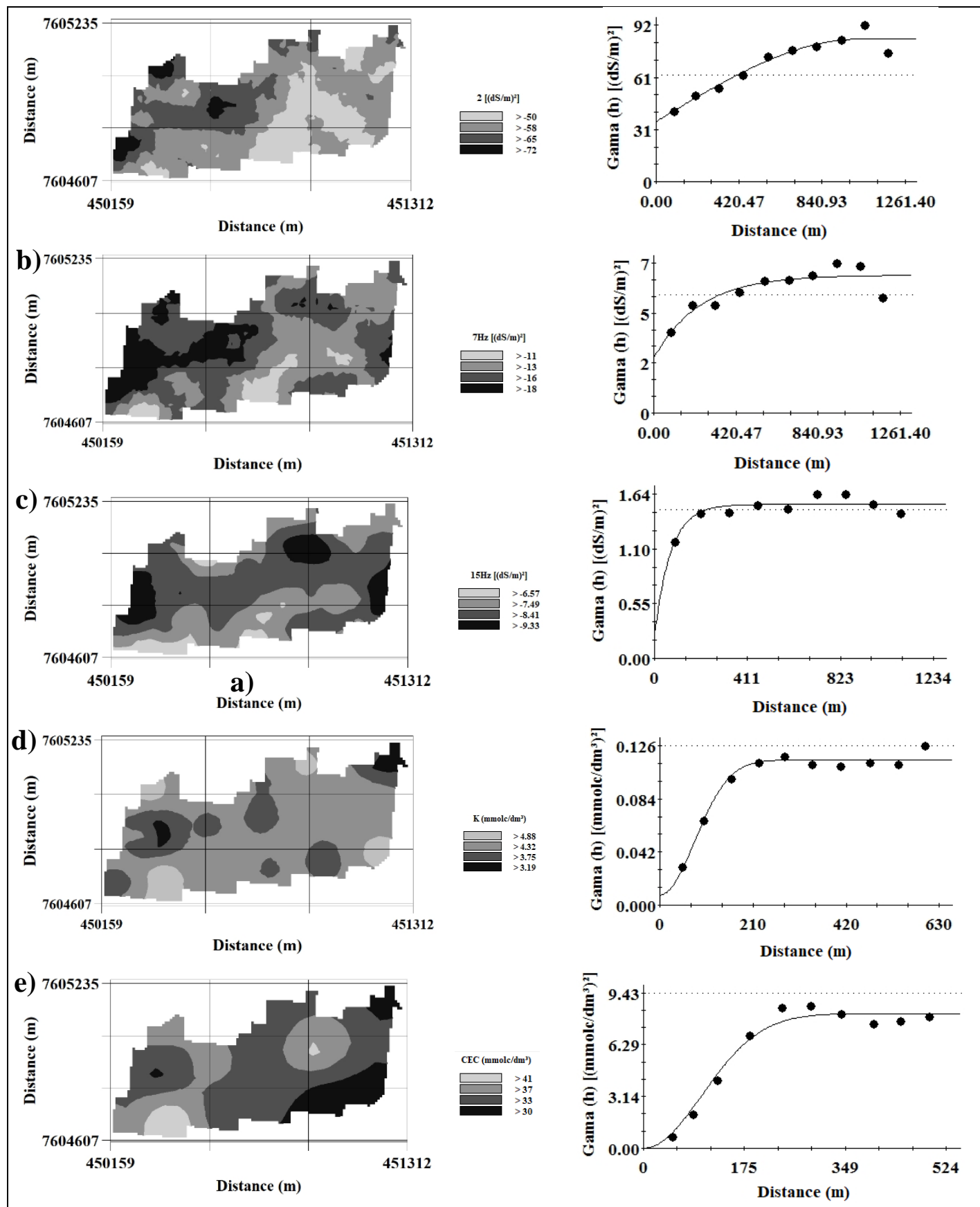

Figure 3. Maps of kriging and semivariograms of apparent electric conductivity and physicochemical attributes of the soil.

Cultura Agronômica, Ilha Solteira, v.26, n.3, p.469-482, 2017 
The decreasing relation of ranges was the following: ECa $2 \mathrm{kHz}(1,032 \mathrm{~m}), \mathrm{ECa} 7 \mathrm{kHz}$ $(885 \mathrm{~m})$ and ECa $15 \mathrm{kHz}(396 \mathrm{~m})$ (Table 3 and Figures 3a, b and c). Determining the semivariogram range allowed inferring about the maximum distance of homogeneity of the evaluated attributes, which were represented in relation to neighboring samples. These results lead to the suggestion of Dalchiavon et al. (2011). According to the aforementioned study, geostatistical gridding and distance between points like these should be used to aid future studies. The values of ranges to be used in geostatistical packages, which will feed the computational packages used in precision agriculture, should be generally between 247.7 and $1,032 \mathrm{~m}$, for representing the distance within which the values of a certain attribute are equal to each other. The range of these attributes ensures that all points in an area with this radius and the same soil are very similar, in such a way to be used to estimate values for any point between them (MACHADO et al., 2006).

In the initial comparison of maps of kriging (Figure 3), in which the management zones based on EC and soil attributes are presented, it is possible to notice spatial resemblance between ECa $2 \mathrm{kHz}$ and ECa $7 \mathrm{kHz}$. Thus, in Figures $3 \mathrm{a}$ and $3 \mathrm{~b}$ in the east-central region of the map are the lowest ECa values. While the western regions of the 2, 7 and $15 \mathrm{kHz} \mathrm{ECa}$ maps (Figures 1a, b, c) showed the highest ECa values. In the same region are the average contents of $\mathrm{K}$ (3.19-3.75 $\mathrm{mmol}_{\mathrm{c}} \mathrm{dm}^{-3}$ ) and CTC (30-33 mmol $\mathrm{dm}^{-3}$ ). However, it is observed that $\mathrm{ECa} 2$ and $7 \mathrm{kHz}$ are very irregular, that is, with small management zones, which according to Alves et al. (2013), small management zones are impossible to be managed due to technical and economic limitations.

\section{CONCLUSION}

The apparent electrical conductivity (ECa) was presented as an important tool to identify specific management zones showing data variability between low and medium.

Attributes that had higher correlation with apparent electrical conductivity were potassium and clay

\section{BIBLIOGRAPHIC REFERENCES}

ALVES, S. M. F.; ALCÂNTARA, G. R.; REIS, E. F.; QUEIROZ, D. M.; VALENTE, D. S. M. Definição de zonas de manejo a partir de mapas de condutividade elétrica e matéria orgânica. Bioscience Journal, Uberlândia, v. 29, n. 1, p.104-114, 2013.

AQUINO, R. E. D.; MARQUES JÚNIOR, J.; CAMPOS, M. C. C. OLIVEIRA, I. A.; SIQUEIRA, D. S. Distribuição espacial de atributos químicos do solo em área de pastagem e floresta. Pesquisa Agropecuária Tropical, Goiânia v. 44, n. 1, p.32-41, 2014.

BERNARDI, A. C. C.; BETTIOL, G. M.; GREGO, C. R.; ANDRADE, R. G.; RABELLO, L. M.; INAMASU, R. Y. Ferramentas de agricultura de precisão como auxílio ao manejo da

Cultura Agronômica, Ilha Solteira, v.26, n.3, p.469-482, 2017 
fertilidade do solo. Cadernos de Ciência \& Tecnologia, Brasília, v. 32, n. 1/2, p.211-227, 2015.

BOTTEGA, E. L.; QUEIROZ, D. M.; SANTOS, N. T.; PINTO, F. A. C.; SOUZA, C. M. A. Correlação entre condutividade elétrica aparente e atributos químicos e físicos de um Latossolo. Comunicata Scientiae, Bom Jesus, v. 6, n. 2, p.134-142, 2015.

CAETANO, J. O.; VERGINASSI, A.; ASSIS, P. C. R.; CARNEIRO, M. A. C.; PAULINO, H. B. Indicadores de qualidade de um Latossolo Vermelho sob diferentes sistemas de uso e manejo. Global Science and Technology, Rio Verde, v. 6, n. 1, p.26-39, 2013.

CARVAlHO, L. C. L.; SILVA, F. M.; FERRAZ, G. A. S.; SILVA, F. C. Variabilidade espacial de atributos físicos do solo e características agronômicas da cultura do café. Coffee Science, Lavras, v. 8, n. 3, p.265-275, 2013.

CORÁ, J. E.; BERALDO, J. M. G. Variabilidade espacial de atributos do solo antes e após calagem e fosfatagem em doses variadas na cultura de cana-de-açúcar. Engenharia Agrícola, Jaboticabal, v. 26, n. 2, p.374-387, 2006.

CORASSA, G. M.; AMADO, T. J. C.; TABALDI, F. M; SCHWALBERT, R. A.; REIMCHE, G. B.; NORA, D. D.; ALBA, P. J.; HORBE, T. A. N. Espacialização em alta resolução de atributos da acidez de Latossolo por meio de sensoriamento em tempo real. Pesquisa Agropecuária Brasileira, Goiânia, v. 51, n. 9, p.1306-1316, 2016.

CRUZ, J. S.; ASSIS JUNIOR, R. N.; MATIAS, S. S. R.; CAMACHO-TAMAYO, J. H.; TAVARES, R. C. Análise espacial de atributos físicos e carbono orgânico em Argissolo Vermelho-Amarelo cultivado com cana-de-açúcar. Ciência e Agrotecnologia, Lavras, v. 34, n. 2, p.271-278, 2010.

DALCHIAVON, F. C.; CARVALHO, M. P.; FREDDI, O. S.; ANDREOTTI, M.; MONTANARI, R. Variabilidade espacial da produtividade do feijoeiro correlacionada com atributos químicos de um Latossolo Vermelho Distroférrico sob sistema de semeadura direta. Revista Bragantia, Campinas, v. 70, n. 4, p.1-9, 2011.

DALCHIAVON, F. C.; CARVALHO, M. P. Correlação linear e espacial dos componentes de produção e produtividade da soja. Semina: Ciências Agrárias, Londrina, v. 33, n. 2, p.541-552. 2012.

DALCHIAVON, F. C.; CARVALHO, M. P.; ANDREOTTI, M.; MONTANARI, R. Variabilidade espacial de atributos da fertilidade de um Latossolo Vermelho Distroférrico sob Sistema Plantio Direto. Revista Ciência Agronômica, Fortaleza, v. 43, n. 3, p.453-461, 2012.

EMPRESA BRASILEIRA DE PESQUISA AGROPECUÁRIA - EMBRAPA. Sistema brasileiro de classificação de solos. 3.ed. Rio de Janeiro: Embrapa, 2013. 353 p.

EMPRESA BRASILEIRA DE PESQUISA AGROPECUÁRIA - EMBRAPA. Manual de métodos de análises de solo. 2.ed. Brasília: Embrapa, 2011. 230 p.

Cultura Agronômica, Ilha Solteira, v.26, n.3, p.469-482, 2017 
FRANCISCO, J. P.; FOLEGATTI, M. V.; SILVA, L. B. D.; SILVA, J. G. B. Monitoramento da condutividade elétrica e $\mathrm{pH}$ da solução do solo sob diferentes doses de aplicação de vinhaça. Revista Engenharia na Agricultura, Viçosa, v. 23, n. 6, p.552-561, 2015.

GEOPHYSICAL SURVEY SYSTEMS. Profiler EMP-400. Nashua: The world leader in subsurface Imaging, 2006. 85 p.

GAMMA DESING SOFTWARE. Geostatistics for environmental sciences 7. ed. Plainwell: Gamma Desing Software, 2004. 159 p.

HOPKINS, W. G. A new view of statistics: Correlation coefficient. Internet Society for Sport Science. 2014. Available in: http://www.sportsci.org/resource/stats/correl.html. Access in: 05 mar. 2017.

KILIC, K.; KILIC, S.; KOCYIGIT, R. Assessment of spatial variability of soil properties in areas under different land use. Bulgarian Journal of Agricultural Science, Sofia, v. 18, n. 5, p.722-732, 2012.

LAMPARELLI, R. A. C.; ROCHA, J. V.; BHORGUI, E. Geoprocessamento e agricultura de precisão - Fundamentos e Aplicações. 1. ed. Guaíba: Agropecuária, 2001. 118 p.

LESCH, S. M.; CORWIN, D. L.; ROBINSON, D. A. Apparent soil electrical conductivity mapping as an agricultural management tool in arid zone soils. Computers and Electronics in Agriculture, Oxford, v. 46, n. 1, p.351-378, 2005.

MACHADO, P. L. O. A.; BERNARDI, A. C. C.; VALÊNCIA, L. I. O.; MOLIN, J. P.; GIMENEZ, L. M.; SILVA, C. A.; ANDRADE, A. G. A.; MADARI, B. E.; MEIRELLES, M. S. P. M. Mapeamento da condutividade elétrica e relação com a argila de latossolo sob plantio direto. Pesquisa Agropecuária Brasileira, Brasília, v. 41, n. 6, p.1023-1031, 2006.

MACHADO, F. C.; MONTANARI, R.; SHIRATSUCHI, L. S.; LOVERA, L. H.; LIMA, E. S. Spatial dependence of electrical conductivity and chemical properties of the soil by electromagnetic induction. Revista Brasileira de Ciência do Solo, Viçosa, v. 39, n. 4, p.1112-1120, 2015.

MARQUES JUNIOR, J.; SOUZA, Z. M.; PEREIRA, G. T.; BARBIERI, D. M. Variabilidade espacial de matéria orgânica, P, K e CTC de um latossolo cultivado. Revista de Biologia e Ciências da Terra, São Cristóvão, v. 8, n. 1 p.143-152, 2008.

PESQUEIRA, A. S.; BACCHI, L. M. A.; GAVASSONI, W. L. Associação de fungicidas no controle da antracnose da soja no Mato Grosso do Sul. Revista Ciências Agronômicas, Fortaleza, v. 47, n. 1, p.203-212, 2016.

PIMENTEL-GOMES, F. P.; GARCIA, C. H. Estatística aplicada a experimentos agronômicos e florestais. 11. ed. Piracicaba: FEALQ, 2002. 309 p.

RAIJ, B. V.; ANDRADE, J. C.; CANTARELlA, H.; QUAGGIO, J. A. Análise química para avaliação da fertilidade de solos tropicais. Campinas: Instituto Agronômico, 2001. $285 \mathrm{p}$.

Cultura Agronômica, Ilha Solteira, v.26, n.3, p.469-482, 2017 
SIQUEIRA, G. M.; SILVA, E. F. F.; DAFONTE, J. Distribuição espacial da condutividade elétrica do solo medida por indução eletromagnética e da produtividade de cana-de-açúcar. Bragantia, Campinas, n. 74, v. 2, p.215-223, 2015.

SCHLOTZHAVER, S. D.; LITTELL, R. C. SAS: system for elementary statical analysis. 2.ed. Cary: SAS, 1997. 905 p.

SOUSA, S. S.; MOREIRA, S. G.; CASTRO, G. F. Avaliação da fertilidade do solo por Agricultura de Precisão e Convencional. Revista Agrogeoambiental, Pouso Alegre, v. 8, n. 1, p.33-46, 2016.

TAVARES FILHO, J.; FELTRAN, C. T. M.; OlIVEIRA, J. D.; ALMEIDA, E.; GUIMARÃES, M. D. F. Atributos de solo determinantes para a estimativa do índice de estabilidade de agregados. Pesquisa Agropecuária Brasileira, Brasília, v. 47, n. 3, p.436441, 2012. 